\title{
PROBLEMS OF PARASITIC SAFETY EVALUATION OF WATER IN SOURCES USED BY POPULATION
}

\section{ПРОБЛЕМЫ ОЦЕНКИ ПАРАЗИТНОЙ БЕЗОПАСНОСТИ ВОДЫ ИСТОЧНИКОВ ВОДОПОЛЬЗОВАНИЯ НАСЕЛЕНИЯ}

\author{
KUZNETSOVA, Kamalya Yu. ; ZELYA, Olga P.; ZHNAKINA, Zhanna V.; MANIYA, Tamari R. \\ Sechenov First Moscow State Medical University \\ 20 Pirogovskaya Str., 119435, Moscow, Russian Federation \\ ${ }^{*}$ Corresponding author \\ kama.123@yandex.ru \\ Received 2018; received in revised form 2018; accepted 2018
}

\section{RESUMO}

A importância do monitoramento estatal dos corpos hídricos nos indicadores parasitológicos é atualizada no artigo. Estabeleceu-se que relatórios resumidos de empresas federais envolvidas no monitoramento estatal de corpos hídricos são formados sem levar em conta os sistemas parasitários naturais e a detecção insuficiente da poluição parasitológica local. Ao mesmo tempo, a taxa de incidência na Federação Russa em relação à giardíase devido ao fator de transporte de água tem sido consistentemente alta por vários anos. Criptosporidiose entre a população não é detectada devido ao uso de métodos insensíveis de diagnóstico. Com um estado tão inexplorado de fatores que afetam a saúde pública, o nível de causas etiológicas não identificadas de infecções intestinais agudas, infecções do trato respiratório superior e pneumonia adquirida na comunidade permanece alto na Federação Russa: $70 \%$ e 90\%, respectivamente. 0 artigo apresenta dados sobre a contaminação parasitária de corpos de água na bacia hidrográfica do rio Moscou, obtidos com uma pesquisa de especialistas independentes.

Palavras-chave: estabelecimento de padrões ambientais (classificação higiênica), índices parasitológicos, monitoramento hidrobiológico, protozoários de vida livre, segurança parasitária.

\section{ABSTRACT}

The importance of state monitoring of water bodies on parasitological indicators is actualized in the article. It was established that summary reports of federal enterprises involved in the state monitoring of water bodies are formed without taking into account natural parasitic systems and insufficient detection of local parasitological pollution. At the same time, the incidence rate in the Russian Federation regarding giardiasis due to the water transport factor has been consistently high for several years. Cryptosporidiosis among the population is not detected due to the use of insensitive methods of diagnosis. With such an unexplored state of factors affecting public health, the level of unidentified etiological causes of acute intestinal infections, upper respiratory tract infections, and community-acquired pneumonia remains high in the Russian Federation: $70 \%$ and $90 \%$, respectively. The article presents data on parasitic contamination of water bodies in the catchment area of the Moskva River, obtained with an independent expert survey.

Keywords: environmental standards (hygienic rating), parasitologic indices, hydrobiological monitoring, freeliving protozoans, parasitic safety.

\section{АННОТАЦИЯ}


В статье актуализируется важность государственного мониторинга водных объектов на паразитологических показателях. Было установлено, что сводные отчеты фредеральных предприятий, участвующих в государственном мониторинге водных объектов, фрормируются без учета природных паразитарных систем и недостаточны для обнаружения местного паразитологического загрязнения. В то же время уровень заболеваемости в Российской Федерации в отношении лямблиоза из-за фактора водного транспорта постоянно был высоким в течение нескольких лет. Криптоспоридиоз среди населения не выявлен из-за использования нечувствительных методов диагностики. При таком неизведанном состоянии факторов, влияющих на здоровье населения, уровень неопределенных этиологических причин острых кишечных инфекций, инфекций верхних дыхательных путей и внебольничной пневмонии остается высоким в Российской Федерации: соответственно 70 и $90 \%$. В статье представлены данные о паразитном загрязнении водных объектов в водосборном бассейне реки Москва, полученном при независимом экспертном опросе.

Ключевые слова: гигиеническое нормирование, паразитологические показатели, гидробиологический мониторине, свободнодвижущиеся простейшие, паразитарная безопасность.

\section{INTRODUCTION}

One of the priority tasks of the Russian Federation Water Strategy is the development of water-bodies' state monitoring system including the development and modernization of the state observation system within the frameworks of the Complex of Russian Water Bodies Control and agreements with the water policy of European Union (Directive..., 2000; Water Strategy..., 2009; Website of Federal Service...). World Health Organization recommends determining the quality of drinking water by the following parasitic parameters: Fasciola hepatica, F.gigantica; types of genus Acanthamoeba; Balamuthia mandrillaris, Naegleria fowleri, Giardia intestinalis, Isospora belli, types of genus Cryptosporidium; Toxoplasma gondii, Balantidium coli (Drinking Water..., 2004). Currently central for our country is the latter 8 , for 5 of which hygienic standards for water epidemic safety have not been developed and the assessment of the water transmission routes risk of these pathogens for people have not been made. Of the listed agents the types of genus Acanthamoeba (Acahthamoebidae family), Balamuthia mandrillaris (Leptomyxidae family) and Naegleria fowleri (Vahlkampfiidae family) refer to the group of free-living water protozoan that can change to the parasitic way of life. There exist more than 11 types that refer to these 3 families, the medical importance of the biggest part of which remains unstudied (Krylov, 1996). Pathogenic power of Naegleria fowleri amebas during the past century was in reasonable detail studied on experimental animals (Centers..., 2011; Clin, 1980; Oddó, 2006; Swanson and
Hammer, 2000) and it was proved that in case of intranasal infection amebas penetrate nasal mucosa, cause its ulceration and destruction, penetrate via the olfactory nerve into b.olfactory, which leads to development of vast brain involvement, acute meningoencephalitis, focal pneumonia and quick death of animals. Numerous experimental and clinical researches proved causation of free-living amebas of Acanthamoebae family in the development of acute respiratory diseases (Cerva, 1967; Chang, 1974; Culbertson, 1971; Gordeeva, 1970, 1978; Pokrovskiy et al., 2009). Independent types of free-living parasitic amebas were systematized into 2 classes: Entamoebidae and Lobosea (the family of Acanthamoebae Sawyer at Griffin, 1975; the family of Hartmanellidae Volkonsky, 1931; the family of Naegleriidae Page, 1976) (Culbertson, 1971; Krylov, 1996).

The group of protozoan free-living in soil and water systems are referred in Russian epidemiology to the agents of sapronosis - "an ancient group of diseases characterized by the absence of any specialization of the agent with respect to the hosts" (Sergiev and Filatov, 2010). However, the existing thesis on discretization of epidemic manifestations of sapronosis infections is subject in this work to critical analysis due to insufficient knowledge on the problem and absence of systematic observation and accumulation of information on the cause and mechanisms of the transformation of the saprophile existence phase of natural one-celled geobionts and reservoir inhabitants into the parasitic one (Onishchenko, 2003). Under the influence of anthropogenic load on the environment during the last years there have 
been observed the activation of biological factors of human environment and changes of stable parasitic ecosystems (Aslanova et al., 2016; Onishchenko, 2003) that "are not investigated in detail from the point of view of classification of their hazard for the health of population" (Guzeeva and Sergiev, 2011). In our research, we adhere to the systematic approach to parasitocenosis as a natural factor determining the multi-component structure of infectious process involved in which are agents of different taxonomical groups. The prove are low indices of etiological exposure of community-acquired pulmonary fevers, acute upper respiratory tract infections with multiple and unspecified localization (up to 90\%) and acute enteric infections of unspecified etiology (more than 70\%) (Guzeeva and Sergiev, 2011; Website of Federal Supervision..., n.d.) of the RF population over the period of many years. Modern condition of public the healthcare can be characterized as a failure of traditional epidemiological and ecological approaches to a health evaluation. The introduction of special account of natural and modified parasitocenosis and integration into the classification of the hazard by groups of water bodies presupposes perfection of legal and regulatory solutions substantiated by the relevant analysis of a single accounting base formed on the basis of dynamic and systematic observation data and its complex evaluation.

Purpose: to present scientifically grounded proposals on the introduction of parasitological indicators into the register of state monitoring of water bodies.

\section{MATERIALS AND METHODS}

A survey was conducted in 24 points of the Moskva River and its main tributaries. (Figure 1). A total of 216 water samples and 216 bottom sediment samples were examined by laboratory methods.

Laboratory methods were used, based on the filtration of 112 water samples, which were passed through analytical membranes $(1.5 \mu \mathrm{m})$. The filtrate was then washed with distilled water and poured into test tubes. The resulting suspension was subjected to centrifugation, and the precipitate was examined. Preparations were previously stained with $1 \%$ Lugol solution and microscopized for the presence of helminthes eggs and protozoan cysts with an increase of $x 100, x 400, x 1000$

Oocysts of cryptosporidium were identified by the method of immunomagnetic separation.

Re: Lugol solution (LS): $5.0 \mathrm{~g}$ iodine $+10.0 \mathrm{KI} \mathrm{g}$ $+100 \mathrm{~m}$ distilled water

$1 \%$ Lugol solution $=5.0 \mathrm{ml} \mathrm{LS}+20.0 \mathrm{ml}$ Physiological saline solution of sodium chloride.

The results are summarized by the method of comparative analysis of the research results in relative values. Statistical tests were not applied.

\section{RESULTS AND DISCUSSION}

The infrastructure of the water-parasitic system in the observed points was represented by such types as Sarcomastigophora - 2.5\%, Ciliophora - 84\%, Microspora - 0.5\%, and differed species diversity: Protey, Entamoeba spp., Paramecium caudatum, Euglena viridis. The causative agents of intestinal protozoal infections were Lamblia intestenalis, L.canis, Balantidium spp., Cryptosporidium spp. (Table 1).

Moskva river. There were conducted 156 studies of water- and bottom silt samples. The share of water samples not corresponding to hygienic requirements by the content of cysts of pathogenic intestinal protozoans L.intestenalis constituted $55.5 \%$. The share of samples containing free-living forms of water protozoans Entamoeba spp. constituted $46.6 \%$.

River Setun: There were conducted 30 studies of water- and bottom silt samples. The share of water samples was not corresponding to hygienic requirements by the content of cysts of pathogenic intestinal protozoans Lamblia spp., Cryptosporidium spp. constituted $66 \%$. The share of samples containing free-living water protozoan Entamoeba spp. constituted $100.0 \%$ (in all research points).

River Skhodnya: There were conducted 18 studies of water- and bottom silt samples. The share of water samples not corresponding to hygienic requirements by the content of cysts of pathogenic intestinal protozoans L.intestenalis, Cr.muris constituted $23 \%$. The share of samples containing free-living water protozoan Entamoeba spp.was $35.0 \%$.

River Yauza: 6 tests of water- and bottom silt samples were conducted. All water samples corresponded to hygienic requirements by 
parasitologic indices. The share of samples containing free-living water protozoan Entamoeba spp. was $15.6 \%$.

B. Novo-Devichiy pond: There were conducted 6 studies of water- and bottom silt samples. There were found cysts of intestinal protozoans L.intestenalis, L.canis, B.coli, Cr.parvum, Cr.muris, and vegetative forms of Entamoebae spp. The share of samples not corresponding to hygienic requirements was $100 \%$.

\section{CONCLUSIONS:}

Preliminary results of conducted by us screening studies of water bodies in the Moscow Region speak for a sufficient prevalence of freeliving protozoan of Amoebae group. This problem presupposes a specialized approach to the study and account of the results, formation of a data base on the bodies of water having an economic significance. The content of cysts and vegetative forms of free-living protozoans of Amoebae group in the researched water bodies constituted around $60 \%$. In $50 \%$ of samples there were found cysts of intestinal protozoans pathogenic for animals; in 4 of 5 water bodies, there were found parasitic pathogens of an intestinal group not accounted for by the official statistics (cysts of intestinal protozoans L.intestenalis, L.canis, B.coli, Cr.parvum, Cr.muris).

Independent data have been obtained on the high level of contamination by pathogens of parasitic diseases of water bodies in the Moscow region, which increases the risk of contamination of people with the use of recreational waters. This is confirmed by the high prevalence of giardiasis (166.65 cases per 100.000 population) and the presence of a potential risk of infection of the population with cryptosporidiosis, respiratory infections of amoeba etiology.

It is established that the federal system of observations does not take into account parasitic pollution and does not possess reliable information on the sanitary status of water bodies on parasitological indicators.

The necessity to incorporate parasitologic indices into a special survey of hydro-biological monitoring will permit, in our opinion, to systematize the database of natural parasitocenosis of water ecosystems by their hazard class and to develop the methods for health risk assessment.

Consolidated data on the condition of water bodies by the indices of parasitic safety is formed separately within the framework of highly specialized departmental researches of the participants of state monitoring and are not included into the single accounting base of the RF water bodies' status; this impedes a fullfledged analysis of relevant factors in contamination by parasitic pathogens of waterconsumption sources and a complex health risk evaluation.

\section{REFERENCES:}

1. Aslanova, M. M.; Kuznetsova, K. Yu.; Morozov, Ye. N.; Effective Laboratory Diagnostics as the Basis of Parasitic Diseases' monitoring, Health of Population and the Living Environment 2016, 1(274), 34.

2. Centers of Disease Control and Prevention/Supervision over the outbreaks of the diseases transferred by water connected with drinking water the USA, 2007-2008, MMWR 2011, 60(No. SS-12), 38.

3. Cerva, L.; Intranasal intrapulmonary and intracardial inoculation of experimental animals with Hartmannella castellanii, Folia Parazitol. 1967, 14(3), 207.

4. Chang, S. L.; Cytopatic and pathogenic differences among geographic strains of pathogenic Naegleria and their bearing on the epidemiology of primary amoebic meningoencephalitis /PAM/, $3^{\text {rd }}$ Intern. Congr. Parazitol., Munich 1974, 187.

5. Clin, J.; The pathogenicity of Legionella in fresh water and soil amoeba, Pathol. 1980, 33, 1179.

6. Culbertson, C. C.; Pathogenic Naegleria and Hartmannella /Acantamoebal, Ann. Rev. Microbiol. 1971, 25, 231.

7. Directive 2000/60/EEC of European Parliament and Council of October 23, 2000.

8. Drinking Water Quality Assurance Manual. World Health Organization, Geneva 2004, 1, 63.

9. Gordeeva, L. M.; Amoebae Limax-group from respiratory tract of man: interaction 
with cellcultures, IV Intern. Congr. Parazitol., Warszawa, Poland, 19-26 VIII 1978, sec. A, 38. Gordeeva, L. M.; Primary Amebic Meningocephalitis caused by free living ameba sp.Hartmannella, Akantamoeba and/or Naegleria, Meditsinskaya parazitologiya $i$ parazitarnye bolezni 1970, 2, 227.

10. Guzeeva, T. M.; Sergiev, V. P.; Condition of Parasitary Diseases Diagnostics in the Russian Federation, Meditsinskaya parazitologiya $i$ parazitarnye bolezni 2011, 4, 43.

11. Krylov, M. V.; Identifier of parasitic protozoans, Zoological Institute: SaintPetersburg, 1996.

12. Oddó, B. David, Infecciones por amebas de vida libre. Comentarios históricos, taxonomía y nomenclatura, protozoología y cuadros anátomoclínicos, Rev Chil Infect 2006; 23(3), 200. Available at: www.sochinf.cl. Accessed on 20/12/2017.

13. Onishchenko, G. G.; Criteria for Determining the Danger of Environment Pollution, Gigiyena i sanitariya 2003, 6, 3.
14. Pokrovskiy, V. I.; Pak, S. G.; Briko, N. I.; Danilkin, B. K.; Infectious Diseases and Epidemiology, 2009.

15. Sergiev, V. P.; Filatov, N. N.; Human and His Parasites: Antagonism of Genomes and Molecular Interaction, Nauka: Moscow, 2010.

16. Swanson, V. S.; Hammer, B.; Legionella pneumophila pathogenesis: a fatal path from amoebas to macrophages, Ann. Rev. microbiol. 2000, 54, 567.

17. Water Strategy of the Russian Federation for a period up to 2020. Approved by the Russian Federation Government Executive Order of August 27, 2009. No. 1235-p.

18. Website of Federal Service for Supervision of Nature Resources. Available at: http://www.mnr.gov.ru. Accessed on 20/12/2017.

19. Website of Federal Supervision Agency for Customer Protection and Human Welfare. Available at: http://rospotrebnadzor.ru. Accessed on 20/12/2017. 
Table 1. Results of parasitological research of water samples from Moskva River and Setun River

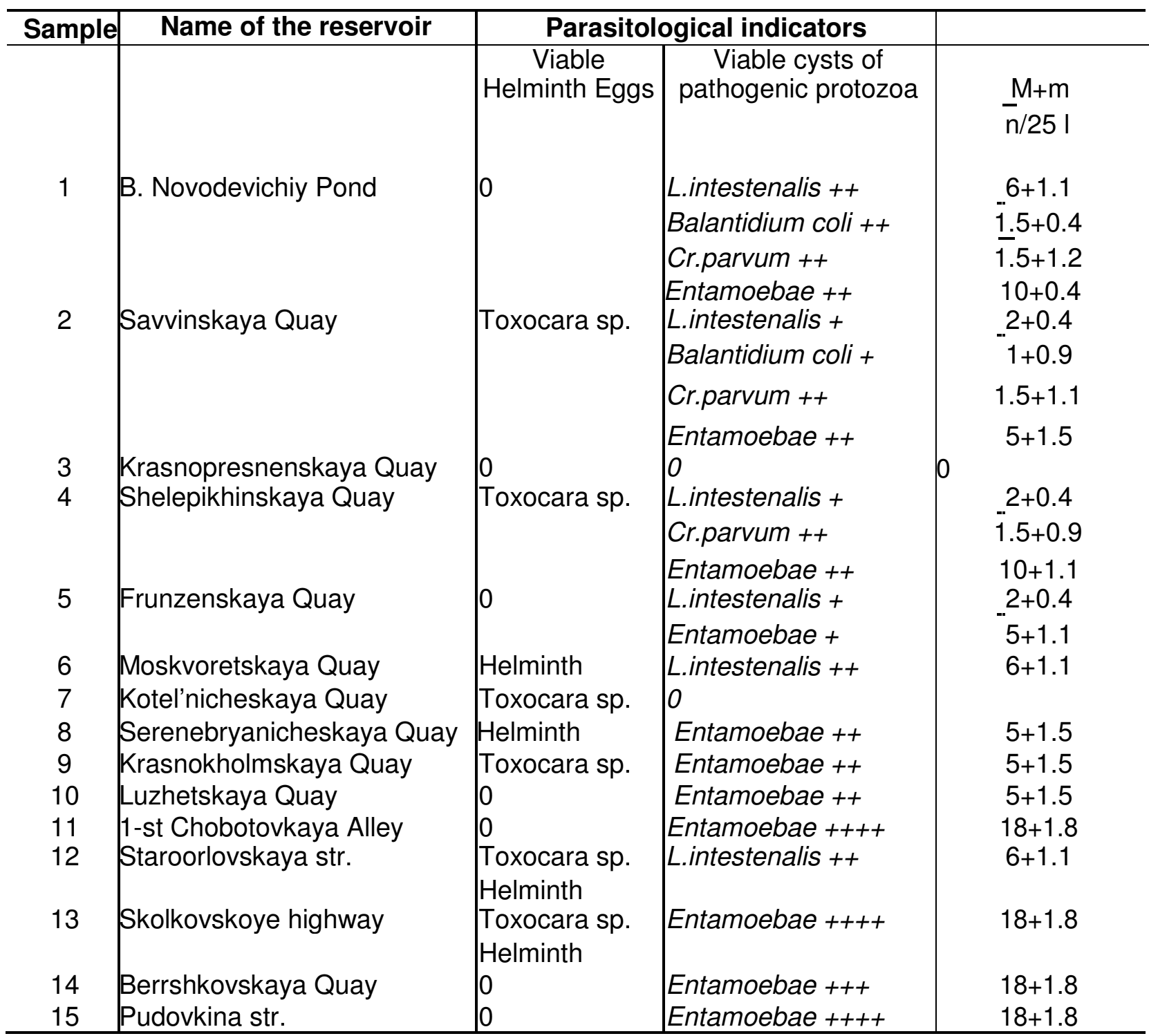




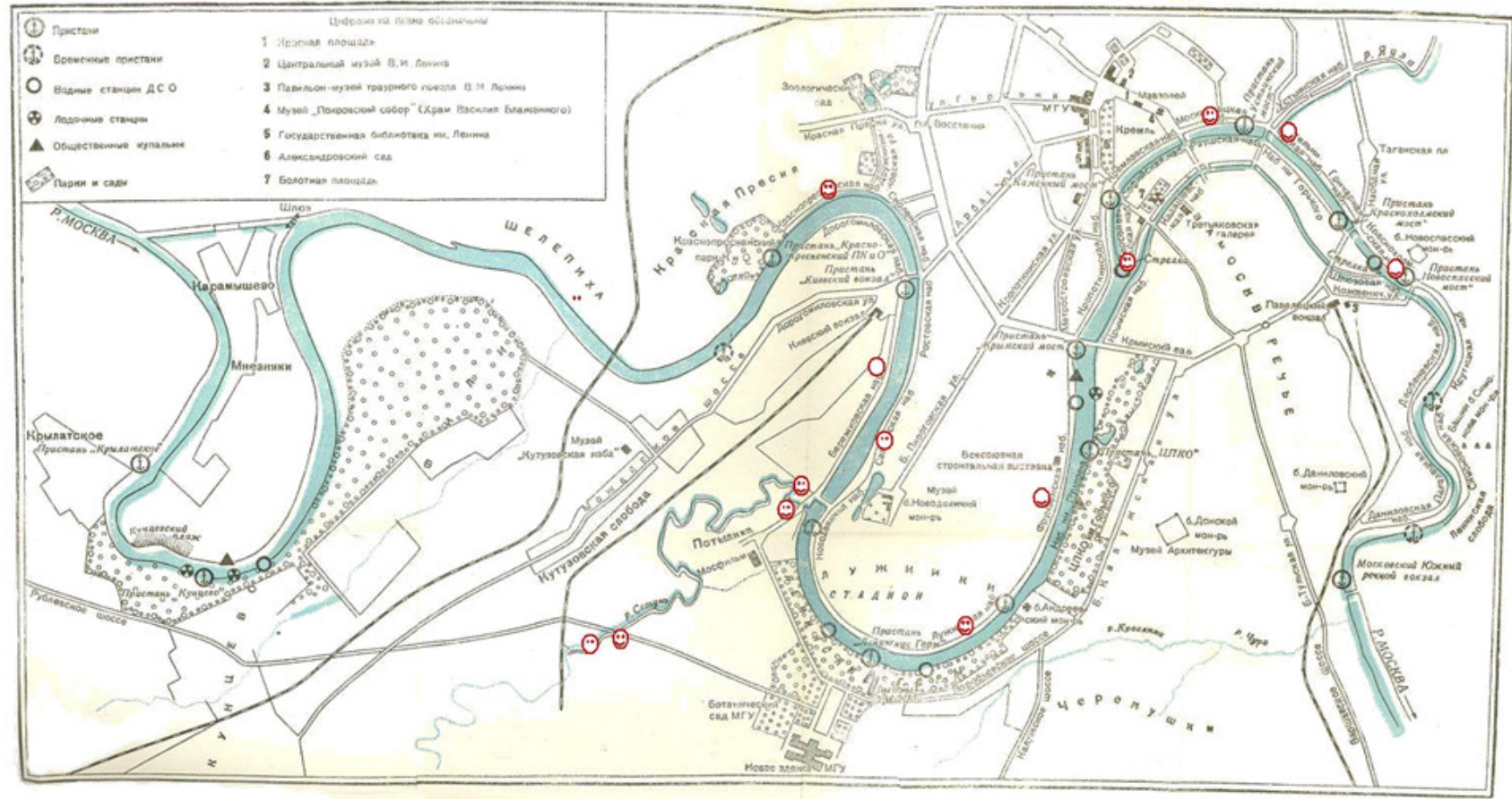

Figure 1.Scheme of the sampling route from the Krylatskoye pier to the South River Port of the Moskva River

Note: $\odot$ - Sampling Point

PERIÓDICO TCHÊ QUÍMICA•www.periodico.tchequimica.com• Vol. 16 N. 31.

- ISSN 1806-0374 (impresso) • ISSN 1806-9827 (CD-ROM) • ISSN 2179-0302 (meio eletrônico) (C) 2019. Porto Alegre, RS. Brasil

The Periódico Tchê Química (ISSN: 1806-0374; 2179-0302) is an open-access journal since 2004. Journal DOI: 10.52571/PTQ. http://www.tchequimica.com. This text was introduced in this file in 2021 for compliance reasons.

OPEN ACCESS. This article is licensed under a Creative Commons Attribution 4.0 (CC BY 4.0) International License, which permits use, sharing, adaptation, distribution, and reproduction in any medium or format, as long in the article 's Cropriate credit to the original author(s) and the source, provide a link to the Creative Commons license, and indicate if changes were made. The images or other third-party material in this article are included regulation or exceeds the permitted use, you will need to obtain permission directly from the copyright holder. To view a copy of this license, visit http://creativecommons.org/licenses/by/4.0/. 